UDC 811

DOI https://doi.org/10.32838/2710-4656/2021.4-2/23

Aliyev S. R.

Baku Slavic University

\title{
DISCOURSE ADEQUACY IN TRANSLATIONS FROM ENGLISH INTO AZERBAIJANI
}

The article deals with the adequacy of discourse in source and target texts. It explains the essence of discourse and adequacy as a linguistic term which displays the inferences based on the works of popular English writers and on their translations into Azerbaijani. It stresses the essence of adequacy in translation, discovers the differences between the adequacy and equivalence, as well as on the ways of achievement of adequacy based on the examples of translations from English into Azerbaijani. The article emphasizes the role of adequacy in the translation of fiction. Moreover, it stresses the role of culture and tradition in both of the texts.

It touches upon the problem of discourse in linguistics. It explains the notion of discourse as a term in linguistics and classifies its types, genres and structures. It also stresses the role of discourse in various fields of science. Besides, the article summarizes the ideas of such linguists as Zellig Harris, Emile Benvenist, Michel Foucault, M. A. K. Halliday, Teun A. van Dijk, Ernesto Laclau, Chantal Mouffe, Robert de Beaugrande, Wallace Chafe, and Norman Fairclough who dealt with the problem of discourse in fiction.

The author of the article gives some examples and analyzes the discourse adequacy on the basis of translations from English into Azerbaijani. He demonstrates examples from the novels of the wellknown American writer John Steinbeck "The Grapes of Wrath" and the popular English writer Julian Barnes "The Sense of an Ending” translated from English into Azerbaijani by Ulfat Kurchayli and Seyfaddin Huseynli. The source and target texts are compared by the author and the discourse adequacy is revealed on the basis of the two texts. The article displays the adequacy of discourses of the writer and translator by basing on some examples from the mentioned novels. The author illustrates the idea of the novels from the point of view of the discourse of characters. We observe that the translators have attempted to create an adequate effect in the target text. It shows the possibility of adequate transformation of the ideas and style from the contrastive languages. The correspondence of discourse of characters and the main idea of novels are implemented into life through the discourse of translators.

Key words: translation, adequacy, equivalence, translation of fiction, differences, contrastive languages.

Discourse as a term appeared in linguistics not long ago, but is frequently used in linguistics. Nevertheless, it does not have a concrete and generally accepted definition. That is why, in the last decades the problem of discourse has kept its topicality in linguistics. It has been studied since the twentieth century and numerous studies have been carried out by such linguists as Michael Halliday, Teun A. van Dijk, Michel Foucault, Ernesto Laclau, Chantal Mouffe, Robert de Beaugrande, Wallace Chafe, Norman Fairclough and other on discourse, as well as on its nature and types $[9, \mathrm{p} .1]$.

We can divide the history of views and studies on discourse into two periods: the first period starts with the introduction of the dichotomy of language and parole by De Saussure and ends with the views of Foucault on the relation between knowledge and discourse. Ferdinand de Saussure, the founder of modern linguistics, rarely used the term discourse. He emphasized that language was the only subject of linguistics, and opposed it to parole. His followers put emphasis on discourse more. Benvenist used the term discourse instead of parole. E. Brusans added discourse to the opposition of language and parole of Ferdinand de Saussure. He thought that discourse was amid language and parole. Language is a system of abstract signs. Discourse is a mechanism of the usage of language by the speaker. Traditional linguistics deals with the study of words and expressions. The second period, starting with Foucault, is still underway. The first period is characterized by the studies of the French-speaking followers of De Saussure, as well as researches of the Englishspeaking linguistic tradition (Z. Harris, 1952) [10, p. 7]. 
English dictionaries define the discourse as a long narration on some topic or a dialogue between two people. Discourse as a linguistic term came into English from the old French, which meant "speech", "judgment" and "opinion". French inherited the term of the discourse from Latin (discursus) and which means "conversation", "discussion", "an act of running about". As a term it was first used in linguistics in 1952 in the article of the American scholar Zelig Harris in his "Discourse analysis". The scholar approached the discourse as a text. He considered the text as an important element in discourse. In general, discourse is ambiguous, but it is also understood as a speech and language activity. Discourse is mainly associated with speech, text and dialogue, and considered an act of communication. It should be noted that discourse is the living speech having a social content. Discourse is related to the language in action and reflects the vocabulary of a particular field. Discourse is a special lexicon, semantics, pragmatics as well as syntax in speech and texts, and it is revealed in the process of communication. Thus, we can come to such a conclusion that there is no discourse without text and context [3, p. 48].

In 1960-1970 discourse was considered as a text. In the late 1980s, the linguists changed their approaches to discourse and was not considered as a text only, but they began to take into account the role of extralinguistic factors as well. In other words, the discourse is not only related to the text, but also non-textual factors are closely related to the discourse. It includes the age, education and outlook of the author, social environment, his attitudes, social status, behaviour and activities in the process of communication. Each of these factors exerts influence on the act of communication. This approach to discourse was proposed by the French linguist M. Foucault. He emphasized the role of the context and situation in the text. He suggested a socio-cognitive approach to discourse. We can note that the thoughts expressed at different levels of social life belong to the discourse. For instance, "scientific discourse", "philosophical discourse", "political discourse" or "medical discourse". In 1960s the French poststructuralists approached the discourse as a way of thinking and studied it on the basis of a real speech. They studied the thoughts of the speaker. Let us have a look at the phrase "racist discourse". People may take a completely various approach when they deal with "racist views", but this exposes the existence of "racist views" in their minds. This arises the question of how the thought, the idea you want to express, is illustrated with the words, and what it means.
In this context, the discourse of the speaker becomes the object of research. Discourse can be found in texts on various topics and in fiction. Discourse can be oral and written, it can be classified into types (individual and institutional discourse), genres (story, interview, conversation, research paper, political speech, court hearings, questionnaire), as well as various fields of human activity, domestic, scientific, formal or criminal [8, p. 57].

New questions arise in the theory of language when we study the concept of discourse. The approach to the sentence as a unit of translation is changing. Discourse is a new field of linguistics, which is complex and difficult to understand. It is particularly and extensively studied in English and French linguistics. Discourse is associated with "speech", "dialogue", "discussion" and "text". There is currently a new approach to discourse in linguistics called discourse analysis. Language is a universal abstract microsystem, but discourse is a concrete subsystem. Discourse is a speech rich in socio-cultural features or a language rich in specific socio-cultural factors. Types of discourse include scientific, political, religious, literary, philosophical and other types. The concepts of discourse and discourse analysis are widely applied to humanities and social sciences. Historians use these concepts in the study of archival documents. Sociology and psychology use discourse in the study of various types of questionnaires and interviews. M. Foucault approached discourse through the prism of language and pointed out the role of culture, literature, science and philosophy in this process particularly. The speeches of the public figures, writers and the Nobel Prize-winners are the striking examples of discourse. Pierre de Ronsard, a 16th century French poet of the Renaissance, called his collection of poems "Discourses", and not in vain. The poet communicated with his readers through his poems $[9$, p. 2].

Contemporary linguists consider discourse a complex act of communication and underline the role of text and non-textual factors in it. They highlight the dynamic nature of discourse and state that the term of discourse is ambiguous, and is related to language and parole. There are different approaches to discourse, whether the parole or the text is more important. The linguists consider the discourse as an act of consecutive communication. The act of communication can be realized through the dialogues and texts. Discourse has its own specific vocabulary, as it can belong to different fields. We can notice the existing moral values and ideology of each epoch in the discourse of that period. In French 
linguistics P. Seriot gave eight different explanations for discourse. It should be noted that this study was conducted only at the French school of discourse analysis. Discourse is also associated with style. We can encounter these expressions in different contexts: "Orwell's style", "Pushkin's language", "Modern Azerbaijani political discourse", "Barack Obama's discourse" and etc. Discourse is closer to the text in terms of sense. In connection with it the linguist Enkvist said, "discourse means text+context, where context contains a situational component". Discourse is dynamic, but text is static. Despite the obvious difficulties in identifying the difference between the text and discourse, the abovementioned definition helps to perceive the difference. Text is a final product or final result, however discourse is a process of text construction. Text can be studied as the real product of certain activity, but discourse is more complex and a general term. Text is a product of language activity. Dialogue is as close to the discourse as well as to the text. As any act of communication, there are two participants in the discourse: the author and the addressee. If we want to study it, we have to unravel the idea and intention of the sender. Any discourse has a structure as well. Thomson and Mann introduce the theory of rhetoric structure. It means that any unit of discourse is related to other units through meaningful relations. Another significant structure of discourse is the information structure. Different linguistic devices belonging to the levels of structure of language are used to construct the information structure in discourse. All these linguistic elements play an essential role in the construction of thematic continuity in discourse. The information structure helps us to keep a certain amount of information in memory. As a result, it ensures global unity in discourse [3, p. 77].

Adequacy is one of the main concepts in the theory of translation. It is understood as the correspondence of the source to the target text. By adequacy the theorists mean a "good" or "correct" translation. It is significant to preserve the communicative function of information in the source text and to translate it in a way to correspond to the target text. There are several types of adequacy: information adequacy, stylistic adequacy, content adequacy, assessment adequacy, systemic adequacy (form and content) [11, p. 78].

The accuracy, consistency and clarity have always been in the focus of attention in the theory of translation. In the recent years, translators have focused their attention on the study of the concept of adequate translation rather than on the concept of equivalent translation. That is natural, because accurate or equivalent translation is not always possible. If we take into consideration the role of subject matter and context, then we can say that the term correspondence or adequacy is more topical for the translation process as ever. V. N. Komissarov was one of the linguists who supported this approach and noted that the concepts of equivalence and adequacy differ from each other. He emphasized that the adequacy is a broader concept and approached the adequate translation as a better option. He approached the equivalent translation as the identity of language units in the source and target texts. The adequate translation was considered by him as a transformation of the main idea and the impression of the original into the target language. The adequacy can be realized as a kind of nominal correspondence. It allows the translator find a kind of "compromise" between the source and target texts. The adequacy is a process of translation and a correspondence between the source and target texts. The correspondence is the coincidence of the meaning in source and target variants [2, p. 221].

Translation of fiction is one of the most difficult type of translation, including its theory. The translators always encounter two issues: preservation of the style of the author and the language of the original, or translation in accordance with the norms of the target language. The fiction is distinguished by its aesthetic effect, figurativeness and abundance of literary description. Different types of transformation are used in order to convey the figurativeness and style, as well as to find an optimal variant [1, p. 222]. Translation of fiction requires professionalism from the translator. Translators must be guided by the principle of creating a similar impression in order to achieve the adequacy between the source and target texts in the translation of fiction. The reader aware of the source text would experience the same feelings when the translated version is read [12, p. 18].

We can provide some examples from the translated novels and study the discourse adequacy in practice. The American writer John Steinbeck's novel "The Grapes of Wrath" (Qəzəb Salxımları) was translated from English into Azerbaijani by Ulfat Kurchayli. Let's look at the adequacy of discourses in source and target texts by demonstrating some examples from the novel: "I climb fences when I got fences to climb," said Tom (Lazım gələrsə, dırmaşıb keçərəm," - dedi Tom); "Hope so", said Tom (Allah elosin, dedi Tom); "Don't bang yaself", said Tom (Başından muğayat ol, - dedi Tom); "The motor roared up for a moment, the gears clicked in" 
(Motor bir anda guruldad, sürot qutusunun ötürücü̈lori şaqqldadi); "He chuckled and walked on" (O, hurıldadı vo yoluna davam etdi); "A bee flew into the cab and buzzed in back of the windshield" (Kabinəyə bir arı girdi və özünü vızıltı ilə ön şüşəyə çırpmăga başladı) [6, p. 22]; "It's a free country. Well, try to get some freedom to do. Fella says you're jus' as free as you got jack to pay for it" (Biz azad ölkədə yaşayırıq. Get onu axtar - azadlı̆̆ı. Biri mənə deyirdi ki, cibindo pul no qadordirso, azadlığın da o qadordir); "Ma looked down at her hands, lying together like tired lovers in her lap" (Ana dizinin üstündə yorğun sevgililar kimi uzanan allorino baxd1); "And her voice was so soft, so full of love, that tears crowded into Rose of Sharon's eyes" (Va onun səsi elə zərif idi, içində o qədər sevgi var idi ki, Şəronlu Rouzun gözlari yaşla doldu), “An' I'm gonna, I'm gonna jus' take his head right down off his neck with that wrench, little piece at a time" (Mən, mən bu açarla onun boynunu sındıracağam, boynuna keçirib asta-asta buracağam) [4, p.7].

The contemporary English writer Julian Barnes's novel "The Sense of an Ending" (Aqibət duyğusu) was translated from English into Azerbaijani by Seyfəddin Hüseynli. Let's look at the correspondence of discourses of the writer and the translator on the basis of some examples from the novel: "We live in time - it holds us and moulds us - but I've never felt I understood it very well" (Hamımı zamanın mohsuluyuq: o, bizi bir yandan ölçür, bir yandan biçir, amma mono elo golir, onu heç vaxt axıracan dərk edə bilməmişəm) [5, p. 9]; "Is there anything more plausible than a second hand? And yet it takes only the smallest pleasure or pain to teach us time's malleability. Some emotions speed it up, others slow it down; occasionally, it seems to go missing - until the eventual point when it really does go missing, never to return" (Saniyo aqrobindon daha hökmlü noso varmı? Ancaq ani bir sevinc, yaxud ötəri bir kədər sayəsindo anlayırıq ki, oslindo, zaman xeyli üzüyoladır. $O$, bozi duyğuların tosirindon yavaşıyır, bir başqa hissin tozyiqi ilo sürot götürür, hərdən də elə bil harasa yox olur, amma lap axırda birdofolik qeybo çəkilir [7, p. 11].

The authors expressed the main idea of the novels with the discourse of characters and created a deep aesthetic effect on the readers. We can say that the translators created an adequate effect in the target text. It displays the possibility of the adequate transformation of the main idea of the writers. The adequacy of discourse of characters and the main idea of the novels are realized through the discourse of translators. In the process of transformation, they emphasize the correspondence and adequacy between the source and target texts. In a nutshell, we do not come across the equivalence of texts on all levels of language, but the discourse adequacy is an optimal variant between the source and target texts.

References:

1. Abdullayeva F. Peşəkar tərcümənin əsasları. Bak1 : UniPrint, 2010.

2. Bayramov Q. H. Tərcümə sənəti. Bakı : OKA Ofset nəşriyyatı, 2008.

3. Hatim B., Mason I. Discourse and the translator. New York : Longman, 1990.

4. Con Steynbek. Seçilmiş əsərləri. Bak1 : "Şərq-Qərb" nəşriyyatı, 2013.

5. Culian Barns. Aqibət duyğusu. Bakı : TEAS Press nəşriyyat evi, 2017.

6. John Steinbeck. The Grapes of Wrath. New York : The Viking Press, 2002.

7. Julian Barnes. The Sense of an Ending. UK : Jonathan Cape, 2011.

8. Mammadov A., Ziyadova L. Discourse and Translation: functional-cognitive approach. Baku : "Letterpress", 2012.

9. Mammadov A. Studies in Text and Discourse. Cambridge Scholars Publishing, 2018.

10. Məmmədov A., Məmmədov M. Diskurs Tədqiqi. "Bak1 Universiteti” nəşriyyatı, 2013.

11. Baker M. Routledge Encyclopedia of Translation Studies. London : Routledge, 1998.

12. Novruzov R. M. Bədii tərcümənin nəzəriyyəsi və təcrübəsi. Bak1 : Mütərcim, 2011.

\section{АЛієв С. Р. АДЕКВАТНІСТЬ ДИСКУРСУ НА ОСНОВІ ПЕРЕКЛАДІВ 3 АНГЛІЙСЬКОЇ МОВИ АЗЕРБАЙДЖАНСЬКОЮ}

У статті досліджуються адекватність дискурсу у вихідному і иільовому текстах. Стаття пояснює сутність дискурсу та адекватності як терміна лінгвістики, який відображає висновки, засновані на роботах популярних письменників. Акиентована сутність адекватності перекладу, розкриваються відмінності між адекватністю та еквівалентністю, а також показані иляхи досягнення адекватності на прикладах перекладів з англійської мови на азербайджанську. У статті підкреслюється роль адекватності під час перекладу художньої літератури. Більш того, у статті підкреслюється роль культури і традиції в обох типах текстів. 
У статті розглядаються проблема дискурсу в лінгвістииі. Стаття пояснює поняття дискурсу як терміна в лінгвістиці і класифікує його типи, жанри і структури. У ній також підкреслюється роль дискурсу з різними галузями науки. Крім того, у статті узагальнені ідеї таких лінгвістів, як Зелліг Харріс, Еміль Бенвеніст, Мішель Фуко, М. А. К. Хеллідей, Теун А. Ван Дійк, Ернесто Лаклан, Шанталь Муфф, Роберт де Богранд, Уоллес Чейф, Норман Фейркло, про проблему дискурсу в художній літературi.

Автор статті наводить приклади та аналізує адекватність дискурсу на основі перекладів з англійської на азербайджанську. Він застосовує на практииі романи відомого американського письменника Джона Стейнбека "Грона гніву» (The Grapes of Wrath) і популярного англійського письменника Джуліана Барнса «Передчуття кіния» (The Sense of an Ending), які були переведені з англійської мови на азербайджсанську Ульфатом Курчайлі і Сейфаддіном Гусейнлі. Автор протиставляє вихідний і иільовий тексти, і в обох текстах виявлясться адекватність дискурсу. У статті на прикладах з романів показана адекватність дискурсів як письменника, так і перекладача. Автори ілюстрували суть романів дискурсом персонажів. Ми бачимо, що перекладачам удалося створити адекватний ефект у цільовому тексті. Це показує можливість адекватної трансформації з контрастивних мов. Адекватність дискурсу персонажів і основна ідея романів втілюеться в життя через дискурс перекладачів.

Ключові слова: переклад, адекватність, еквівалентність, художній переклад, відмінності, контрастивні мови. 